\title{
ANAESTHETIC CONSIDERATIONS IN DOWN'S SYNDROME: EXPERIENCE WITH 100 PATIENTS AND A REVIEW OF THE LITERATURE
}

\author{
Martin Kobel, R.E. Creighton, D.J. Steward
}

\begin{abstract}
Down's Syndrome (Trisomy 21, T21) occurs in approximately 0.15 per cent of live births, In addition to the stigmata of the syndrome, other congenital defects are frequently found in these patients. Cardiac lesions are particularly prominent.

To determine the complications associated with anaesthesia and surgery we examined the records of 100 consecutive patients ( 58 males, 42 females) who underwent surgery with general anaesthesia during a two year period, from March 1978-March 1980.

In addition to the cardiac lesions, the low birth weight of Trisomy 21 infants, increased suceptibility to infections, atlanto-occipital dislocation, and reduced central nervous system catecholamine levels might be expected to result in an increased incidence of complications.

This study of 100 patients with Trisomy 21 (T21) indicates that the incidence of complications is low. However, the anaesthetist must understand the pathophysiology of T21 in order to provide optimal anaesthetic care
\end{abstract}

KEY WORDS: ANAESTHESIA, paediatric; CompliCATIONS, congenital defects, Down's syndrome.

Down's SYNDROME or trisomy 21 (T21) is a relatively common disorder found in approximately 1.5 per 1000 live births. ${ }^{1}$ Because of the association of T21 with other congenital defects, children with Down's syndrome frequently present for surgical procedures that require general anaesthesia. Although much has been written during the past decade about the anaesthetic management of patients with $\mathrm{T} 21$, no in-depth review of the problem has appeared in the anaesthetic literature. The purpose of this paper is to discuss the implications of $\mathrm{T} 21$ for the anaesthetist and to report a retrospective survey of the course of anaesthesia and postoperative recovery in 100 paediatric patients with $\mathrm{T} 21$.

M. Kobel M.D., Resident in Anaesthesia, Department of Anaesthesia, The Hopsital for Sick Children, Toronto*; R.E. Creighton M.D., F.R.C.P.(C), Staff Anaesthetist, The Hospital for Sick Children, Toronto, and Associate Professor, University of Toronto; D.J. Steward M.B., F.R.C.P.(C), Anaesthetist-inChief, The Hospital for Sick Children, Toronto, and Professor of Anaesthesia, University of Toronto.

*Dr. Kobel's Present Address: Department of Anaesthesia, Hopital Cantonal, Bd de la Cluse, 1211. Geneva, Switzerland.

Reprint requests to: Dr. D.J. Steward, Department of Anaesthesia, The Hospital for Sick Children, 555 University Avenue, Toronto, Ontario, Canada, M5G 1 X8. 593

\section{Clinical Study}

We reviewed the records of 100 consecutive patients (58 males, 42 females) with T21 who underwent surgery with general anaesthesia during a two year period (March 1978-March 1980).

The preoperative records were examined for the presence of other congenital anomalies and acquired illnesses. Preoperative weight, vital signs and haemoglobin level were recorded as well as composition, dosage and route of administration of preoperative medication.

The intra-operative anaesthetic record was examined to determine the effect of preoperative atropine on the heart rate, the size of tracheal tube used, and the incidence of complications during anaesthesia. The post-anaesthetic recovery record was also examined for complications and duration of stay in the Post Anaesthesia Room (PAR).

An age and sex-matched group of children without T21 defect served as the control group for comparison

\section{RESULTS}

At operation the patients with $\mathrm{T} 21$ defect ranged in age from one day to 18 years (mean 5.8

Can. Anaesth. Soc. J., vol. 29, no. 6, November 1982 
years); age distribution is shown in Figure 1. The children's weights at operation were below those of normal children (Figure 2); 71 per cent of the patients with $\mathrm{T} 21$ were below the 10 th percentile.

In addition to the stigmata of Trisomy 21,44 patients had lesions which required cardiac surgery (Table I). Forty-one other patients who had non-cardiac operations had congenital abnormalities or concurrent diseases with anaesthetic implications (Table II).

All surgical procedures done in these patients are listed in Table I. The effect of atropine on heart rate at the start of anaesthesia did not differ significantly in patients with $T 21$ defect and controls (Table III).

The sizes of tracheal tubes used for children with T21 are shown in Figure 3; 23 per cent of the tubes inserted were 1 or 2 sizes smaller in diameter than those predicted for age. Previously undiagnosed congenital subglottic stenosis was discovered in one patient during tracheal intubation.

Anaesthesia was induced with intravenous thiopentone in 84 patients and inhalation agents in eight. The eight patients with cardiac lesions received intravenous ketamine. Anaesthesia was maintained with nitrous oxide and halothane, methoxyflurane or narcotic analgesics. Nondepolarizing muscle relaxants were administered as indicated. There were no complications during operation.

In cases of minor surgery, discharge from the PAR was dictated by the speed of recovery from anaesthesia rather than by the need for special observation or nursing care. The mean duration of stay in the PAR was 15 minutes longer for patients with $\mathrm{T} 21$ defect (58.4 \pm 5 minutes) than for controls ( $43.8 \pm 3.5$ minutes).

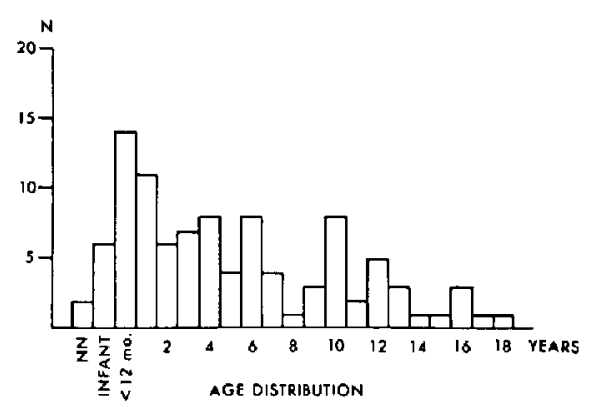

FIGURE 1 Age distribution at operation of patients with $T 21$ defect.

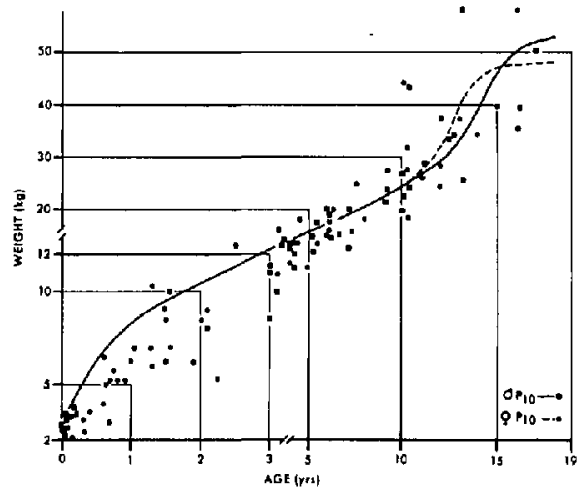

FIGURE 2 Weights at operation compared to weights of normal children.

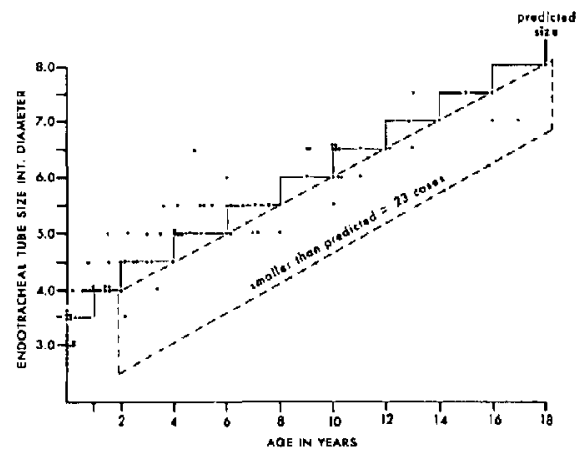

FIGURE 3 Sizes of tracheal tubes used in children with T21 defect. Those smaller than predicted fall on or within the dotted lines.

Respiratory complications occurred in 13 of the T21 patients during the PAR stay (Table IV). Special manoeuvres were necessary to maintain an adequate airway in 10 of these and postintubation stridor developed in two, one of whom eventually required tracheostomy. One patient exhibited marked respiratory depression following tonsillectomy and adenoidectomy done using a ketamine, nitrous oxide and methoxyflurane anaesthetic technique.

\section{Discussion}

Life expectancy for children with $\mathrm{T} 2 \mathrm{l}$ defect has increased dramatically during the past two decades. In 1958, Carter ${ }^{2}$ reported that 30 per cent of children with $T 21$ died in their first month, 53 per cent in their first year, and 70 per cent within their first 10 years. Today 67 per cent of all males and 61 per cent of all females with 
TABLE I

Surgical Procedures for Which General anaesthesia Was Required

\begin{tabular}{|c|c|c|}
\hline $\begin{array}{l}\text { Type of } \\
\text { Procedure }\end{array}$ & $\begin{array}{c}\text { No. } \\
\text { Performed }\end{array}$ & Specific Procedures (number) \\
\hline Cardiac & 44 & $\begin{array}{l}\text { A-V canal repair (19) } \\
\text { ASD and VSD repair (6) } \\
\text { VSD repair (4) } \\
\text { PDA ligation (3) } \\
\text { Mitral valve repair (2) } \\
\text { ASD repair (2) } \\
\text { Palliative surgery: Blalock-Taussig shunt (2) } \\
\text { PA banding (2) } \\
\text { Miscellaneous (4) }\end{array}$ \\
\hline ENT & 19 & $\begin{array}{l}\text { Tonsillectomy and adenoidectomy (13) } \\
\text { Myringotomies and mastoidectomies (4) } \\
\text { Laryngo-bronchoscopy (2) }\end{array}$ \\
\hline General Surgery & 16 & $\begin{array}{l}\text { GU surgery (10) } \\
\text { Duodenoplasty (3) } \\
\text { Pull through (2) } \\
\text { Colectomy (1) }\end{array}$ \\
\hline Ophthalmology & 12 & $\begin{array}{l}\text { Cataract needling and vitrectomy (5) } \\
\text { Squint repair (4) } \\
\text { EUA (3) }\end{array}$ \\
\hline Orthopaedic & 8 & $\begin{array}{l}\text { Cl-C2 fusion (2) } \\
\text { Tendon transfer and osteotomies (3) } \\
\text { Others (3) }\end{array}$ \\
\hline Other & 1 & VP shunt $(1)$ \\
\hline Total & 100 & \\
\hline
\end{tabular}

TABLE II

Congenital Abnormalities and Concurrent Diseases With ANAESTHESIA IMPLICATIONS

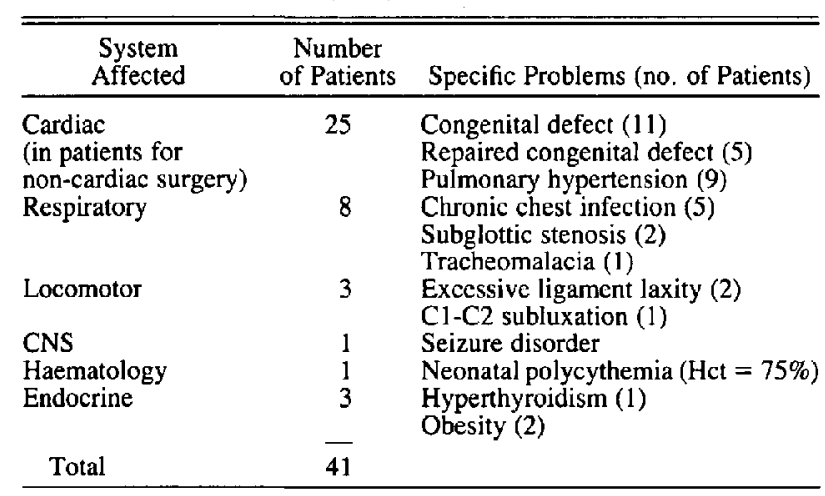

TABLE III

Effect of Premedication on Heart Rate (HR)

\begin{tabular}{ccr}
\hline \multicolumn{1}{c}{ Premedication } & $\begin{array}{c}\text { Dose } \\
\mu \mathrm{g} \cdot \mathrm{kg}^{-1}\end{array}$ & $\begin{array}{c}\text { Mean } \\
\text { Change in HR }\end{array}$ \\
\hline Atropine I.V. (Down's) $\mathrm{n}=38$ & 18.9 & $+33.2 \pm 3.9 \%$ \\
Atropine I.V. (non-Down's) $\mathrm{n}=38$ & 18.09 & $36.1 \pm 3.8 \%$ \\
\hline
\end{tabular}


TABLE IV

RECOVERY ROOM COMPIICATIONS

\begin{tabular}{lcc}
\hline \hline \multicolumn{1}{c}{ Complications } & $\begin{array}{c}\text { No. of Patients } \\
\text { Affected }\end{array}$ & Comment \\
\hline $\begin{array}{l}\text { Post-intubation croup } \\
\text { A/W support required }\end{array}$ & 2 & $\begin{array}{c}\text { l case required tracheotomy } \\
\text { Either oropharyngeal A/W or } \\
\text { holding of jaw } \\
\text { Respiratory rate 7/min after } \\
\text { ketamine/methoxyflurane } \\
\text { anaesthesia }\end{array}$ \\
\hline
\end{tabular}

T21 defect are expected to survive beyond 10 years of age. However, when the T21 defect is associated with congenital heart disease (CHD) only 49.9 per cent of males and 32 per cent of females are expected to survive to age 10 , in contrast to the 76 per cent survival in children without associated CHD. ${ }^{3}$

The intellectual potential of these children is also being re-evaluated. Children with T21 defect who are reared at home by their families commonly show only mild (59-69 I.Q.) to moderate (35-49 I.Q.) retardation. However, physical defects represent a significant handicap and interfere with their development. Hence an increasing number of these children can be expected to be referred for surgery and will require general anaesthesia.

Infants with T21 defect are below average weight; 20 per cent weigh less than $2500 \mathrm{gm}$ at birth. ${ }^{4}$ The underlying genetic abnormality is considered to be responsible for the low weight, which persists into childhood. However, retarded growth may also be related to other factors, such as associated CHD, chronic infections and social conditions. Thus it is important to consider size, weight and age when anaesthetizing children with T21 defect.

Children with T21 defect may have associated disease of great significance to the anaesthetist. Cardiac lesions, for example, are very common among them; 12 per cent of cases have clinically apparent disease and 60 per cent of autopsy studies indicate cardiac lesions. ${ }^{5}$ The incidence of specific cardiac lesions in children with T21 defect is different from that in the remaining population. Endocardial cushion defect is the most common lesion ( 40 per cent), followed by ventricular septal defect (VSD) (27 per cent), patent ductus arteriosus ( 12 per cent) and tetralogy of Fallot (TOF) (8 per cent). ${ }^{5}$ All these lesions, with the exception of TOF, result in increased pulmonary blood flow and may be complicated by pulmonary vascular disease. It has been suggested that children with T21 defect have an increased tendency to develop pulmonary vascular disease $e^{6,7}$ and that this may occur in the absence of other cardiovascular lesions. Possible factors leading to the development of pulmonary vascular disease in T21 children include chronic hypoxaemia secondary to pulmonary infections, hypoventilation due to muscle hypotonia ${ }^{8}$ and obstructive sleep apnoea: ${ }^{9}$ Despite the suggested predisposition to pulmonary vascular disease the mortality associated with cardiac surgery is not increased for children with T21 defect. 10,11

Many children with T21 defect present for general anaesthesia after successful repair of congenital heart lesions. Some of them may be asymptomatic while others may have residual defects limiting their activity. Conduction disturbances are common following repair of $A-V$ canal, TOF and VSD. ${ }^{12}$ Atrial rhythm anomalies are common after repair of transposition of the great arteries with an atrial baffle. ${ }^{13}$

Prophylactic antibiotics are indicated before any surgical procedure for some children even after they have had corrective heart surgery. Those who have had aortic valvotomy, resection of coarctation of the aorta, pulmonary valvotomy, any valve replacement or repair of tetralogy of Fallot or transposition of the great vessels should receive antibiotics. ${ }^{14}$ Those who have had ligation of patent ductus arteriosus and closure of atrial or ventricular septal defect do not require antibiotics. Since even nasotracheal intubation causes bacteraemia, a child at risk should be given prophylactic antibiotics when undergoing any procedure that includes nasal intubation.

Children with T21 defect are prone to infections, particularly those affecting the upper airways and lungs. This may result from the underlying genetic anomaly or a described immune deficiency ${ }^{15}$ but may also be related to institutionalization or social conditions. The 
anaesthetist should note the high incidence of pulmonary infections and relative frequency of positive hepatitis-associated antigen. ${ }^{16}$ The thymus-dependent immune system is more severely depressed than the humoral ( $\beta$ cell related) response. ${ }^{17}$ Although it is not considered practical to avoid immunosuppressive anaesthetic agents for $\mathrm{T} 21$ patients, caution should be exercised to ensure asepsis in the performance of vascular cannulations. Central lines should be removed as soon as possible after operation.

A less recognized complication in T21 children, but one of special importance to anaesthetists, is atlanto-occipital dislocation. This may occur in 12 per cent of children with T21 defect. ${ }^{18}$ Joint instability due to excessive laxity of ligaments is possible in any joint but if $i$ occurs in the cervical spine there is increased likelihood of damage during laryngoscopy, intubation or positioning for surgery. Atlantooccipital instability can be detected clinically using Sharp and Purser's test. ${ }^{19}$ However, this procedure requires a cooperative patient and therefore an $\mathrm{x}$-ray diagnosis must often be relied upon. Neck radiographs should be done on all T21 patients with gait disturbance or abnormality of neck motion. ${ }^{20}$ Excessive laxity of other joints (e.g. finger, thumb, elbow or knee) is easier to detect and correlates well with the presence of atlanto-occipital dislocation. The anaesthetists should be particularly careful to avoid forceful flexion of the neck when managing patients with $\mathrm{T} 21$ defect.

Polycythaemia with haematocrit values over 70 per cent is a frequent finding in neonates with $\mathrm{T} 21$ defect $^{21}$ and patients with a haematocrit as high as 88 per cent have been reported. In the latter case immediate phlebotomy is required to relieve life-threatening circulatory failure. ${ }^{22}$

Thyroid function in patients with $\mathrm{T} 21$ defect has been thoroughly investigated. In his original description in 1866 Down sought to differentiate patients with this syndrome from those with infantile hypothyroidism. Although thyroid antibodies are found in children with $\mathrm{T} 21$ defect, thyroid function is usually normal. In patients who reach adulthood there is a high incidence (possibly 50 per cent) of thyroid hypofunction. ${ }^{23}$

The reported sensitivity to atropine of patients with $\mathrm{T} 21$ defect has interested anaesthetists. Both an exaggerated mydriatic response to ocular atropine ${ }^{24}$ and an increased response of the heart rate to parenteral atropine have been documented. ${ }^{25} \mathrm{~A}$ later study confirmed the mydriatic effect but failed to verify the increased cardiac response. ${ }^{26}$ From a practical point of view, we have observed no ill effects after using standard doses of atropine in children with $\mathrm{T} 2 \mathrm{I}$ defect. In addition, it is probably advisable to ensure an adequate vagal blockade in children with T21 defect, as evidence suggests that they have decreased sympathetic activity. ${ }^{27}$

Children with T21 defect are known to have an increased incidence of congenital subglottic stenosis ${ }^{28}$ and it is possible that all such children have a smaller subglottic area than normal children. Of the T21 patients whose records were reviewed, 20 per cent had been intubated with smaller tubes than would be expected for their age. However, as has already been discussed, patients with $\mathrm{T} 21$ defect tend to be small for their ages and therefore the use of smaller tracheal tubes may be due to the small size of the patient at a given age. Nevertheless, it is recommended that the anaesthetist have a selection of tubes prepared, be alert to the possibility of congenital subglottic stenosis, and carefully select a tube which will allow a leak on positive pressure ventilation.

The response of children with $\mathrm{T} 21$ defect to inhaled anaesthetic agents is thought to be similar to that of normal children; no abnormal reactions have been reported. The minimal alveolar concentration (MAC) for volatile anaesthetic agents has not been measured in children with T21 defect. A reduction of central nervous system catecholamine levels may reduce MAC. ${ }^{29}$ Enzymes responsible for serotonin and catecholamine inactivation show reduced activity in the plasma of $\mathrm{T} 21$ patients but little is known of the brain levels of these compounds. During anaesthesia the heart rate and blood pressure are usually very stable in T21 patients. This could either suggest that deeper levels of anaesthesia are achieved with the standard inhaled concentrations or reflect decreased catecholamine release by peripheral automonic nerve endings. Dopamine- $\beta$-hydroxylase does not increase in the plasma of $T 21$ patients following exercise stress as it does in normal patients. ${ }^{30}$ This could indicate a lower level of peripheral sympathetic activity. The blood pressure in T21 patients is significantly lower when compared to that in normal children or other retarded children. ${ }^{31,32}$

In the postoperative period, airway problems are principally due to the anatomical features of the $T 21$ patient and especially to the large tongue. Sleep-induced ventilatory dysfunction occurs in T21 patients ${ }^{9}$ and may be exacerbated 
by narcotic sedation and residual anaesthetic levels. Close observation is essential until the patient is fully recovered from anaesthesia. Heavy narcotic sedation should be administered only if the patient can be continuously and closely supervised.

\section{Conclusions}

Many patients with $\mathrm{T} 21$ defect will require general anaesthesia. Despite the additional difficulties which might be expected in managing them, the incidence of complications during and after operation is low. The anaesthetist must understand the pathophysiology of this condition so that he can provide optimum management for these patients.

\section{REFERENCES}

1. Nelson, W.E., Vaughan, V.C. \& McKay, R.J. (Eds.). Textbook of Pediatrics. 1lth ed. Philadelphia: Saunders (1979), p. 352.

2. CARTER, C.O. A life-table for mongols with the causes of death. J. Ment. Defic. Res. 2.64 (1958).

3. Fabia, J. \& Drolette, M. Life tables up to age of 10 for mongols with and without congenital heart defect. J. Ment. Defic. Res. 14:235 (1970).

4. Chen, A.T.L., Sergovich, F.R., MCKim, J.S., BarR, M.L. \& GRUBER, D. Studies in full-term, low-birth weight, mentally retarded patients. J. Pediatr. 76: 393 (1970).

5. Greenwood, R.D. \& Nadas, A.S. The clinical course of cardiac disease in Down's syndrome. Pediatrics 58: 893 (1976).

6. ChI, T.L. \& Krovetz, L.J. The pulmonary vascular bed in children with Down syndrome. J. Pediatr. 86: 533 (1975)

7. Wilson, S.K., Hutchins, G.M. \& NeIll, C.A. Hypertensive pulmonary vascular disease in Down syndrome. J. Pediatr. 95: 722 (1979).

8. Rosengart, R.M. \& ISabel-Jones, J.B. Pulmonary vascular involvement in Down syndrome. J. Pediatr. 88: 161 (1976).

9. Clark, R.W., Schmidt, H.S. \& Schuller, D.E. Sleep-induced ventilatory dysfunction in Down's syndrome. Arch. Intern. Med. 140: 45 (1980).

10. Katlic, M.R., Clarke, E.B., Neitl, C. \& HALLER, J.A. Surgical management of congenital heart disease in Down's syndrome. J. Thorac. Cardiovasc. Surg. 74: 204 (1977).

11. FeINGold, M. down's syndrome and heart surgery. Pediatrics 61: 331 (1978).

12. Downing, J.W. JR., Kaplan, S. \& Bove, K.E Postsurgical left anterior hemiblock and right bundle-branch block. Br. Heart J. 34: 263 (1972).

13. ScotT, J.G. \& Allan, D. Anaesthesia for dentistry in children: a review of 101 surgical procedures. Can. Anaes. Soc. J. 17: 391 (1970).
14. Kaplan, S. The adolescent with operated or unoperated congenital heart disease. Postgrad. Med. 56: 147 (1974).

15. ABLIN, R.J. Immunity in Down's syndrome. Eur. J. Pediatr. 127: 149 (1978).

16. SutNick, A.I., London, W.T., Blumberg, B.S. \& GerstLey, B.J.S. Anicteric hepatitis with Australia antigen in patients with Down's syndrome. Am. J. Clin. Pathol. 57: 2 (1972).

17. Levin, S., Schlesinger, M., Handzel, Z., Hahn, T, Altman, Y., Czernobilsky, B. \& Boss, J. Thymic deficiency in Down's syndrome. Pediatrics 63: 80 (1979).

18. Semine, A.A., ErTel, A.N., Goldberg, M.J. \& Bull, M.J. Cervicalspine instability in children with Down syndrome (trisomy 21). J. Bone and Joint Surg. 60-A: 649 (1978).

19. HoDGKINSON, R. Anesthetic management of a parturient with severe juvenile rheumatoid arthritis. Anes. Analg. (Cleve.) 60:611 (1981).

20. Whaley, W.J. \& Gray, W.D. Atlantoaxial dislocation and Down's syndrome. Can. Med. Assoc. J. 123: 35 (1980).

21. Lappalainen, J. \& Louvalainen, K. High hematocrits in newboms with Down's syndrome. Clin. Pediatr. (Phila.) 11: 472 (1972)

22. KOHNE, E \& KiEIHAUER, E. Beziehungen zwischen Polyglobulie und Hämglobinmuster bei Neugeborenen mit $G$ Trisomie. Klin. Wochenschr. 53: 111 (1975).

23. Baxter, R.G., Larkins, R.G., Martin, F.I.R., Heyma, P., Myles, K. \& Ryan, L. Down syndrome and thyroid function in adults. Lancet 2: 794 (1975).

24. Berg, J.M., Brandon, M.W.G. \& Kirman, B.H. Atropine in mongolism. Lancet 2: 441 (1959).

25. Harris, W.S. \& Goodman, R.M. Hyper-reactivity to atropine in Down's syndrome. N. Eng. J. Med. 279: 407 (1968).

26. Mir, G.H. \& CuMming, G.R. Response to atropine in Down's syndrome. Arch. Dis. Child. 46: 61 (1971).

27. Keele, D.K., Richards, C., Brown, J. \& MARSHALl, J. Catecholamine metabolism in Down's syndrome. Am. J. Ment. Defic. 74: 125 (1969).

28. Steward, D.J. Congenital abnormalities as a possible factor in the aetiology of post-intubation subglottic stenosis. Can. Anaes. Soc. J, 17: 388 (1970).

29. EGer, E.I., II, Mac. In Eger, E.I., II (Ed.) Anesthetic Uptake and Action. Baltimore: Williams \& Wilkins (1974), p. 17

30. Coleman, M., Campbell, M., Freedman, L.S., RofFMAN, M., EBSTEIN, R.P. \& GoldSTEIN, M. Serum dopamine- $\beta$-hydroxylase levels in Down's syndrome. Clin. Genet. 5: 312 (1974).

31. Murdoch J.C., Rodger, J.C., RaO, S.S., Fletcher, C.D. \& Dunnigan, M.G. Down's syndrome: an atheroma-free model? Br. Med. J. 2: $226(1977)$.

32. Richards, B.W. \& Enver, F. Blood pressure in Down's syndrome. J. Ment. Defic. Res. 23: 123 (1979). 


\section{Résumé}

Le syndrome de Down ou Trisomie 21 survient environ dans 0.15 pour cent des cas de naissances vivantes. En plus des stigmates caractéristiques du syndrome, on retrouve fréquemment chez ces patients d'autres lésions congénitales en particulier des malformations cardiaques. Parmi les autres pathologies fréquemment retrouvées chez eux et susceptibles d'élever l'incidence des complications anesthésiques et chirurgicales chez ces patients, on retiendra leur tendance à être petits à la naissance ( 20 pour cent d'entre eux pèsent moins de $2500 \mathrm{gm}$ ), la susceptibilité accrue à l'infection, la laxité ligamentaire excessive importante à reconnaître surtout au niveau du cou (la luxation atlanto-occipitale peut survenir chez 12 pour cent des cas de trisomie 21) et les bas niveaux de catécholamines au niveau du système nerveux central.

Nous avons revisé les dossiers de 100 cas consécutifs de patients porteurs du syndrome opérés sous anesthésie générale entre les mois de mars 1978 et mars 1980 , ceci dans le but d'établir l'incidence des complications chirurgicales et anesthésiques. Cette incidence s'est avêrée basse dans notre série.

Il est important que l'anesthésiste comprenne bien la physiopathologie de ces malades s'il veut leur fournir des soins de qualité. 